\title{
Shakespeare Reception in China
}

\author{
Yanna Sun \\ Department of Foreign Languages, Zhengzhou University of Light Industry, China \\ Email: sunyanna@yahoo.com.cn
}

\begin{abstract}
Since the name of Shakespeare was first introduced into China, Shakespeare in China has witnessed several different development phases in the fields of translating, performing and criticism. In whichever phase the characteristic of Shakespearean studies in China was closely associated with the historical, cultural and political situation at that time, the complete disappearance from the Chinese public life during the Cultural Revolution, for instance. Thereupon, some scholar has asserted that the Chinese have misunderstood Shakeseare, even appropriated him for their own purposes. Although the political element did play an important leading role in China's reception of Shakespeare, it is doubtless that any literature must have its potential social function, no matter in terms of artistic or social value. So is the case with Shakespeare in China. The history of Shakespeare reception in China has completely mirrored the Chinese's seeking after truth from western literature at different historical stages.
\end{abstract}

Index Terms-Shakespeare reception, China, historical phases, seeking after truth

Different from any other country with regard to importing Shakespeare, China "followed neither the nationalist model established in central Europe in the eighteenth century, nor the imperialist model of the nineteenth and early twentieth centuries. Instead it followed almost directly the political condition and changing circumstances of the country."(Kennedy, 1993) Strictly speaking, the beginning of China's reception of Shakespeare was carried out under the threat of gunboat diplomacy from Great Britain, as Takeuchi Yoshimi contended: "The modern Orient was born only when it was invaded, defeated, and exploited by the West." (Huang, 2004) Over the course of more than one hundred years of exposure to the playwright, the Chinese have changed their attitudes towards him and his works, from rejecting him as a cultural agent of Western imperialism to welcoming him as a popular playwright and poet in the world and finally to integrating him and his works into Chinese culture, albeit influenced by certain historical factors, including politics, economy, culture, and society.

The whole process of acceptance can be divided into eight phases and will be analyzed in detail in the following parts. In fact, the ebb and flow of Shakespearean reception in China mirrors the development of Chinese attitudes in adapting Western culture to Chinese society and culture.

\section{Initial Phase (From Mid-19 ${ }^{\mathrm{TH}}$ Century to the Turn of $20^{\mathrm{TH}}$ Century)}

Meng Xianqiang has noted, "[t]he first man who translated the name of Shakespeare into Chinese was Lin Zexu (1785-1850), a politician and senior official (Governor of Hu-Guang province) in the late Qing dynasty (1640-1911)." (Meng, 2002)

Lin Zexu was a national hero in the Sino-British Opium War (1840-1842). Entrusted by the Emperor of the Qing dynasty, Lin went to Hunan and Guangdong provinces to ban the illegal British opium trade which not only cost China enormous sums of money but also brought harm to the health and moral quality of those Chinese who were addicted to the drug. In addition, after realizing the Qing government had completely isolated itself from the rest of the world, Lin organized his people to translate Western books and newspapers, in order to counteract the invasion of Western countries through acquiring a better understanding of their politics, history, geography and technology. At this time, however, Shakespeare appeared as one of the Elizabethan poets in Lin's translation of Hugh Murray's (1789-1845) Cyclopedia of Geography (1836), which was published in 1839 under the title Annals of Four Continents.

The Opium War forced China, a country with its own history of more than two thousand years of feudal society, to open her doors to the West. The War, followed by a series of unequal treaties between China and Western countries, marked China's great change from a feudal kingdom to a semi-colonial and semi-feudal country in her history.

After the 1850s English and American missionaries came to China and many missionary schools were established as a way to introduce Western civilization to China. The name of Shakespeare was often mentioned as a great poet and dramatist of the Elizabethan age in regard to the translations of various books on culture, geography and history done by the missionaries. (Li, 1991)

Having learned its lesson from being defeated in the Sino-British Opium War, the Qing government took measures to strengthen its military force, for example, by bringing several battleships from foreign countries and building factories producing weapons. In the meantime, the government sent groups of students and scholars to Europe and Japan to study science and technology. After coming back to China, these scholars with enlightened thought devoted their time to translating Western works of philosophy, ethics and economics. Yan Fu (1853-1921) was one of them: he had studied in England for a few years. In his 1895 translation of English philosophical, political and economic classics, Thomas 
Huxley's (1825-1895) Evolution and Ethics and Other Essays (1893) for instance, he mentioned Shakespeare's plays and characters. Instead of introducing the playwright and his works to China, Yan Fu's mention of Shakespeare was to illustrate Western ideas:

Shakespeare wrote a play recounting the murder of Caesar. When Antony delivers a speech to the citizens while showing the body of Caesar to the public, he uses logic to stir up the citizens cleverly because Brutus warned him that he would not be allowed to redress a grievance for Caesar and blame the murderers. The citizens are greatly agitated by the speech and their resentment against Brutus and his comrades is running high. We should attribute Antony's success to the function of logic! (Zhang, 1996)

During the initial phase, the Chinese knew nothing about Shakespeare other than his reputation as a poet and playwright in England. In a word, Shakespeare and his works were ignored at the very early stage in the history, regarded as "a cultural agent of Western imperialism" (Berry, 1998). The main reasons can be summarised as follows: on the one hand, from the Chinese point of view, China's self-sufficient natural economy was destroyed by the English invasion during the Opium War and the Chinese began to suffer humiliation from a series of unequal treaties afterwards. Accordingly, the patriotic Chinese strongly resisted the introduction of Western culture, regarding it as a cultural invasion following the military invasion; on the other hand, England was the first Western country to force China to open her doors to the West through importing illegal opium into China. Undoubtedly, as a result of having been invaded, and with the aim of "learning the advanced techniques of foreign countries in order to resist them", as stated by Wei Yuan (1794-1857) in the late period of the Qing dynasty, the Chinese were only interested in learning from Westerners about their technology, economics and geography. The name of Shakespeare was introduced to China only among some translations of English history and geography. Consequently, the first reception phase of Shakespeare in China was completely outside the field of art and literature.

By the way, during the first phase of Shakespearean reception in China, the name of Shakespeare was transliterated in various ways, such as Shashibia by Lin Zexu, Shekesibi by William Muirhead (1822-1900), Shaisibier by Joseph Edkins (1823-1905), and Shasipier by Devello Z. Sheffield (1841-1913), an American priest. It was only in 1902 that Liang Qichao (1873-1929) fixed transliterating Shakespeare as Shashibiya in his On Poetry, which was published in New Citizens' Journal. (Meng, 1994)

\section{Transitional Phase (From 1903 to 1920)}

Some Chinese scholars are of the opinion that the real acceptance of Shakespeare in China did not begin until the year 1903 when the first Chinese translation of Shakespeare was in print, for the previous references to Shakespeare by English and American missionaries as well as Chinese scholars simply introduced his name without describing his plays or poems in detail. They are not wrong in terms of art and literature, nevertheless, the name of Shakespeare became known to the Chinese during the Opium War, even though only to a small circle and accordingly, from the historical viewpoint it is reasonable to look back on the history of Shakespearean reception in China as from Lin Zexu's rendering Western military, technical and geographical works in the period of his banning British opium trade in Guangdong province.

At the beginning of the twentieth century, Chinese intellectuals advocated studying Western culture in order to integrate "the Chinese philosophy of life and Western standards of precision and efficiency" (Li, 1991). Shakespeare gradually came to be known by more and more Chinese. During this period a number of scholars tried to translate his plays into Chinese and consequently the Chinese audience and reader had the opportunity to appreciate his works rather than only know his name.

Strictly speaking, during the early years of the twentieth century the Chinese reader did not have access to Shakespeare's plays apart from through a collection of Tales from Shakespeare (1807) by Charles and Mary Lamb. Shakespeare was received at that time in China not as a poet or playwright but as a fiction writer and story-teller, inasmuch as the translations gave some general ideas about plots, characters and themes. The first translation of this collection was published anonymously under the title of Strange Tales from Overseas in 1903, but it included only ten of the tales and arranged them as ten chapters of a novel. One year later (1904), Lin Shu (1852-1924), who was a famous writer and translator but had no knowledge of foreign languages at all, cooperated with Wei Yi, a translator and master of several foreign languages, in translating the complete Tales from Shakespeare into Chinese under the title The Mysterious Stories of the English Poet. Then in 1916 with the help of Chen Jialin, Lin Shu retold five of Shakespeare's original plays, namely, Richard II, Henry IV, Henry V, Henry VI and Julius Caesar. Unfortunately, he translated these plays once again in classical Chinese prose instead of the form of drama. Lin's Mysterious Stories of the English Poet offered scripts for new drama - the early drama in China and once popular in Shanghai at the beginning of the twentieth century.

Though not complete, the earliest Chinese rendition of a Shakespearean original play appeared about 1910. After watching Gounod's opera Romeo and Juliet in New York performed by Amelita Galli-Curci, Chang Chen-hsien claimed, Deng Yizhe was excited by the play and translated the balcony scene into a rhymed ballad. Unfortunately, "one who cannot read the original text can never understand what Deng says. One who can will discover, after taking all the trouble to trace a line by line comparison, that much of the translation does not make any sense at all." (Chang, 1953) 
During this period Western works were all translated into classical Chinese. "With the gradual introduction of Western science and art, Chinese intellectuals at the beginning of the twentieth century felt a pressing need to replace classical Chinese with the vernacular for general communication and even for intellectual discourse and literature." (He, 1986) The New Cultural Movement started in 1917 under the guidance of Hu Shi (1891-1962), who promoted the use of vernacular and called for the total removal of the classical language. Resulting from this Literary Revolution, translations of Western works began to appear in modern Chinese language. Accompanied by other Western literature, parts of Shakespeare's plays were for the first time introduced in dramatic form to China.

\section{REAL BEGINNINGS OF CHINESE ShaKESPEARE (FROM 1921 TO 1949)}

In 1921 Tian Han (1898-1968), a playwright and translator, ambitiously attempted to translate ten plays of Shakespeare within three or four years - in fact, he did the first complete Chinese translation of Shakespeare, that of Hamlet, which was published by the China Publishing House in 1922, and afterwards of Romeo and Juliet in 1924. He was the first to translate a complete Shakespeare play in its original dramatic form into modern Chinese. Apart from Tian's renditions of Shakespeare before 1949, many scholars have been involved in translating Shakespearean dramas and sonnets into modern Chinese. Two of them are worth mentioning: one is Liang Shiqiu (1902-1987) from Taiwan and the other is Zhu Shenghao (1912-1944) from mainland China. They both have greatly contributed to the translation of the dramatist's complete plays.

Liang Shiqiu began his translation of Shakespeare in 1931 when he was on the mainland and translated eight of the dramatist's plays in this decade. He did not finish the rest until 1967, eighteen years after he moved to Taiwan. His translations of Shakespeare's complete plays were published by the Far East Publishing Company in Taiwan. Zhu Shenghao, at the encouragement from his colleague Zhan Wenhu (1905-1973) against the historical background that there had never been a translation of a foreign writer's complete works, started in the year 1935 with his ambitious plan to finish translating Shakespeare's complete works within two years. Zhu first finished rendering The Tempest in 1936. His failure to carry out his plan on schedule resulted from two facts. On the one hand, his manuscripts were destroyed twice during the Japanese invasion and he had to retranslate them. On the other hand, unfortunately, he died of illness and from poverty at an early age of thirty-two after he had finished rendering thirty-one and a half of Shakespeare's plays. Twenty-seven of his translations were first published by the Shanghai World Publishing House in 1947.

Between 1921 and 1949 many Chinese scholars chose their favourite Shakespearean dramas to be translated and rendered the plays in their own style. As a result, there were several versions of the same play at the same time. Meanwhile, the scholars aimed to offer scripts for stage presentation. For example, in 1930 the Shanghai Drama Association - on the basis of the translation of Gu Zhongyi (1903-1965) - performed The Merchant of Venice, the first performance of a full-length Shakespearean drama on the Chinese stage. During this phase the theatrical participants tried to perform Shakespeare's plays on the Chinese stage in the Western dramatic style, following the Western scenes and dressing up like Westerners with high noses and blue eyes. However, because most Shakespearean plays did not suit the taste and need of the time, the attempt to stage Shakespeare in China was not successful.

In terms of Shakespearean criticism, the relatively late introduction to, and appreciation of, Shakespeare in China compared to other countries in the world, resulted in a lack of Chinese critical works on Shakespeare. The Chinese Shakespearean scholars embarked on Shakespearean criticism by introducing Western criticism of Shakespeare in the 1930s. Between 1934 and 1936 six essays on Shakespeare and his works were printed in Translations, with Today Shakespeare by an Englishman, Germans and Shakespeare by Japanese, and the rest by the Soviet scholars.

Although academic scholars and students made a great effort to render his works into Chinese, which was positive inasmuch as Shakespeare was no longer on the margin, he was nevertheless still beyond the common Chinese reader, who was not enthusiastic about Western culture, because "anti-foreign feeling, constant warfare and momentous social changes in the first half of this century diverted the attention of the Chinese people from even an introductory study of Shakespearean drama." (He, 1986)

\section{DAWning of Chinese ShaKeSPEAREAN CRITICISM (IN THE 1950s)}

After the founding of the People's Republic of China in 1949, the relationship between China and the Soviet Union as allies became much closer than before. Indiscriminately China followed her "Elder Brother", the Soviet Union, in every aspect ranging from political and economic orders to cultural appreciations, for "the good experience of foreign countries, especially Soviet experience, can serve as our guide" (Mao, 1942). Shakespeare was regarded as an important Western writer for Soviet critics and Soviet theatre; accordingly, more and more Chinese academics were encouraged to study Shakespeare and his works. Meanwhile Marx's and Engels's interest in Shakespearean works has particularly inspired Chinese Marxists to interpret the dramatist and his plays. In a letter to the German socialist Ferdinand Lassalle (1825-1862) dated May 18 of 1859, Engels championed Shakespeare:

The realistic should not be neglected in favor of the intellectual elements, not Shakespeare in favor of Schiller [...] What wonderfully distinctive character portraits are to be found during this period of the breakdown of feudalism penniless ruling kings, impoverished hireling soldiers and adventurers of all sorts - a Falstaffian background that, in an historical play of this type, would be much more effective than in Shakespeare! (Huang, 2004) 
Under such political and social circumstances, Chinese interest in Shakespeare and his plays was awakened and Shakespearean studies, for the first time, reached a peak in the 1950s in the fields of translating, performing, cinema and literary criticism.

In 1954, Zhu Shenghao's translations of Shakespeare were published in twelve volumes by the Beijing's Author's Press, and this time his complete translations were included in this collection. The 1954 edition was reprinted in 1958 and 1962 respectively. At the same time other translators' renderings of Shakespeare also came into print, such as Cao Yu's (1910-1996) Romeo and Juliet and Bian Zhilin's Hamlet, and Fang Ping's Venus and Adonis, all of which made a great contribution to Shakespearean studies and translations in China.

Meanwhile, the Chinese continued attempting to perform Shakespeare and his plays. Three institutions - the Central Academy of Drama in Beijing, the Shanghai Theater Academy, and the Beijing Film Academy - were set up to follow the Stanislavsky model and Soviet directors, Yevgeniya Konstantinovna Lipkovskaya (1902-1990) as an example, were invited by the Chinese Communist Party to work as drama teachers at these institutions. He Qixin has stated that in 1956 graduates of a Chinese actors' training school performed Romeo and Juliet in Beijing in the modern Chinese dramatic form - a form which resembles the Western-style drama and which was initiated by a group of Chinese students studying in Japan in 1907. On the other hand, under the guidance of the Soviet experts in directing and acting, Stanislavsky's concept of "starting from the self of the actor" was theorized in demonstrating a realistic representation of life on the Chinese stage. For instance, while directing Shakespeare's Much Ado About Nothing in Shanghai in 1957, Lipkovskaya required her Chinese students to wear costumes in rehearsals, to write autobiographies of the characters and to ask themselves many "if" questions in order to strengthen their imagination that they lived in "Merry England" words by Engels in his The Conditions of the Working Class in England, as Stanislavsky claimed: "If acts as a lever to lift the world of actuality into the realm of imagination" (Li, 2003). During the 1950s, Shakespeare's Much Ado about Nothing and Twelfth Night were frequently adapted for the Chinese stage on the basis of Zhu Shenghao's version.

Throughout the decade, film versions of Shakespeare's plays began to be shown in the cinema either with Chinese dubbing or captions. The earliest screened in China was the well-known film Hamlet with Laurence Olivier. Its Chinese title was The Story of the Prince's Revenge and dubbed in 1958 on the basis of Bian Zhilin's translation. Sun Daolin (1921-2007), who was good at English and a famous actor and director in China, gave the dubbing of the protagonist Hamlet. His familiarity with the English language and his perfect dubbing skills won him a good reputation and meanwhile attracted more and more Chinese audiences to watch the film.

This phase plays rather an important role in the history of Chinese reception of Shakespeare: Chinese Shakespearean criticism was dawning. In other words, in addition to translating and staging Shakespearean works, Chinese scholars began to state their understanding of Shakespearean plays through critical essays in journals. Resulting from the close political relationship between China and the Soviet Union and also the relatively late beginning of Shakespearean studies in China compared to other countries, Chinese Shakespearean scholars followed their elder brother's steps without any hesitation. Many Russian critical essays - two of them are worth mentioning for their frequent appearance in Chinese translations: Shakespeare in the Soviet Union by Mikhail Mikhailovich Morozov (1897-1952), published in China in 1953 with two Chinese translations: one by Wu Ningkun (1921-) and the other by Wu Yishan, and Alexander Anikst's Shakespeare and His Plays published in China in 1957 - were translated into the Chinese language so that Chinese critics could appreciate Russian attitudes towards and opinions about Shakespeare and his plays, to the extent of being indispensable as reference books for teaching foreign literature and Shakespeare's plays at the department of the Chinese Language and Foreign Languages. Under the strong influence of established research paradigms from the Soviet Union - Marxist criticism of Shakespeare, the Chinese critics concentrated on discussing the historical background of Shakespearean works, social conflicts and class relations expressed in them, regarding the plays as representatives of realism and approving Shakespeare's humanism in them. (Meng, 1994) In point of fact, the popularization of analyzing Shakespeare and his works in China from the viewpoint of class was partially due to Mao Zedong's call "to never forget class struggle" in the 1950s, which was first mentioned in his talks in 1942:

The writers and artists should study society, that is to say, they should research into every class in society, into their mutual relationship and their individual situation, into their physiognomy and psychology. Only when we fully understand all these, can we have a literature and art that is rich in content and correct in direction. (Mao, 1942)

No matter which social class William Shakespeare stood for - ironically, there was no working class or proletariat in Shakespeare's time - and how Chinese scholars followed the established research paradigms in the Soviet Union, it was undeniable that Shakespearean criticism came into its own in China in the 1950s.

\section{A Halt to Shakespearean Studies (During the Cultural Revolution of 1966 to 1976)}

The period of the Cultural Revolution was a big disaster in Chinese history. Ultra-leftists purified the Party by purging the so-called "bourgeois" and anti-socialist tendencies. They attacked all traditional values and strongly objected to foreign literature, considering that Western culture and bourgeois things could corrupt proletarian ideas and socialist ideology. Instead, the celebration and eulogy of workers, peasants and soldiers became the core idea in art and literature. The prevailing political instability had a great impact on Chinese economic growth, social stability, educational progress and diplomatic policy. China was once again shut off from the outside world and Shakespeare disappeared completely from the lips and pens of the Chinese. 
Every day the Chinese were asked to recite and memorize Quotations from Chairman Mao, which were collected in a pocket-size book with a red plastic cover, known as "Little Red Book". Almost every Chinese person had such a Red Book in his or her pocket. In addition, in bookstores and libraries Quotations from Chairman Mao and so-called new proletarian literature took the place of any other book and newspaper, including all foreign literature which was labelled as "feudal, bourgeois or revisionist" and was then banned. Those scholars and teachers who had studied Western works were cruelly denounced in public by the Red Guards. The only plays performed on the stage were eight so-called "model dramas", different from either typical Chinese theatre or Western dramatic style, to sing the praises of Chairman Mao and the "red" proletarian ideas. Without exception, under the propaganda that all literature and art should serve socialism and Chinese writers should address workers, peasants and soldiers, everything about Shakespeare and his works in China was completely removed from bookstores, libraries, stages, cinemas and any other public place, although some Chinese intellectuals carried on reading Shakespeare in private. The boom of Chinese Shakespearean studies that had been awakened in the 1950 s came regrettably to a halt.

\section{Resuscitation of Shakespearean Studies (AFTER the Cultural Revolution)}

After the end of the disastrous Cultural Revolution in 1976, Shakespeare and his works came back to the Chinese along with other Western literature. Obviously, suffering from being banned as "feudal, bourgeois or revisionist" by the ultra-left members of the Chinese Communist Party during the Cultural Revolution for ten years, Shakespearean studies in China needed time to resuscitate themselves. During this period, the noticeable characteristic was that the strong influence of Marxist proletariat literary criticism upon interpretations and appreciations of the English playwright still dominated the Shakespeare scholarship in China.

In the late 1970s two great events encouraged Chinese scholars to take up Shakespearean studies again. One was the British Old Vic Company's performances in China and the other was the publishing of The Complete Works of Shakespeare. This collection included a revised version of Zhu Shenghao's complete translations of thirty-one plays together with renditions of the other six plays and was printed in 1978 , a schedule originally for celebrating the $400^{\text {th }}$ anniversary of Shakespeare's birth in 1964, which was delayed by the Cultural Revolution. The revision was carried out by Fang Ping, Fang Zhong and Wu Xinghua (1921-1966), following the principle of trying to preserve the characteristics of the original translation and improving the quality of the old version by correcting mistakes as carefully as possible and supplementing what had been deleted. In addition to Zhu Shenghao's complete rendition of Shakespeare, translations of history plays including that of Henry $V$ by Fang Ping, Henry VI (part 1, 2, 3) by Zhang Yi (1901-1986), Henry VIII by Yang Zhouhan and Richard III by Fang Zhong were all added to the Complete Works, together with Yang Deyu's The Rape of Lucrece, Zhang Guruo's (1903-1994) Venus and Adonis, Huang Yushi's A Lover's Complaint and Liang Zongdai's (1903-1983) The Sonnets. The publishing of The Complete Works of Shakespeare marked the very beginning of Chinese translations of a foreign writer's complete works and has had a great significance in the history of Chinese literature. One year later, the British Old Vic Company with Derek Jacobi brought Shakespeare's Hamlet to Chinese audiences. The performances were carried out in Beijing and Shanghai respectively. Unfortunately, many spectators could not understand English well and had to depend on the Chinese translation through earphones.

Much Ado about Nothing staged by the Shanghai Youth Huaju Theatre Company in 1978 was the beginning of Shakespearean performance in China after the Cultural Revolution, being called "a swallow informing the coming of spring”. (Meng, 1994)

At the same time, some critical essays on Shakespearean plays were published in many resumed and newly started journals. However, in the late 1970s Chinese Shakespearean critics were not able to cut out the influence of the Cultural Revolution's class struggle and analysis, for "there was no official denouncement of this political upheaval and a number of political and ideological issues remained unresolved." (He, 1986) They still adhered to the Marxist approach and Mao Zedong's political criteria for literary criticism, claiming that there was no literature that could climb above social classes and accordingly every author wrote for a particular class. For example, the aforementioned Yang Zhouhan held that the British playwright and poet Shakespeare was a bourgeois writer and "was writing for the emerging bourgeois class although he himself might not have been aware of this fact" (He, 1986).

\section{The Flowering OF ShaKespearean Studies (FrOM the 1980S to the END OF 20Th CENTURY)}

After coming into power in 1981, Deng Xiaoping (1904-1997) advocated opening China's doors to the world and initiated economic reforms, pioneering socialism with Chinese characteristics by saying "regardless of whether it is a white or black cat, it is a good cat if it can succeed in catching mice". Consequently, the Chinese witnessed monumental social, economic and political changes, which simultaneously ensured immense enthusiasm in the Chinese reception of Shakespeare, finally bringing a promising flowering in the history of Chinese appreciation and interpretation of Shakespeare. Against a new historical, social and cultural background, Chinese scholars approached Shakespeare from the aspect of new ideologies, values and aesthetic tastes.

On the stage, Chinese directors and adaptors made great efforts to perform Shakespearean dramas either in English or Chinese in two forms: as spoken drama and/or as traditional Chinese theatre. Ying Ruocheng (1929-2003), a 
well-known translator, actor and director, adapted and directed Measure for Measure with the help of the visiting director Toby Robertson, which was a successful adaptation of Shakespearean play on the Chinese stage. In the same year 1981, a group of students from Tibet performed Romeo and Juliet in the Tibetan language at the Shanghai Drama Institute in order to "broaden the horizon of the staging of Shakespeare in China" (He, 1986). Apart from the new dramatic form of spoken drama, during this period many Shakespearean plays were also adapted for the traditional Chinese stage, the Beijing opera of Othello in Beijing in 1983, for instance. What is more, Shakespeare was transplanted onto the Chinese stage in various traditional theatrical forms during the first Chinese Shakespeare Festival celebrated in 1986, ranging from Beijing opera, kunju opera, Shaoxing opera, yueju opera, to huangmei opera.

In the field of translating, many Chinese renditions of Shakespearean works came into print, for example, Bian Zhilin, Sun Dayu (1905-1997) and Yang Lie respectively published their poetic versions of Shakespeare's Four Great Tragedies. Even more popular was the introduction of Liang Shiqiu's The Complete Plays of Shakespeare to mainland China for the first time in 1996. Two years later, experts on English literature and drama such as Qiu Kean, He Qixin, Shen Lin and Gu Zhengkun were invited to revise Zhu Shenghao's rendition of Shakespeare published in 1978 and then the Yilin Publishing House printed the revised version of The Complete Works of Shakespeare (supplement) with the help of Suo Tianzhang, Sun Fali, Liu Bingshan and Gu Zhengkun in retranslating and enlarging Shakespeare with the newly found The Two Noble Kinsmen and Edward III. So far the supplement collects the most complete works of Shakespeare in China.

Besides translating, Chinese academics have actively published their studies of, and research into Shakespeare, as Meng Xianqiang estimated that "during the last two decades, they produced five Shakespearean monographs, eighteen collections of essays on Shakespeare, and five various types of Shakespeare dictionaries", (Meng, 2002) for example, Fang Ping's Making Friends with Shakespeare, including his seventeen essays on Shakespeare between the late 1970s and early 1980s. In these critical essays on Shakespeare and his works, "Chinese scholars have done [with] polemical discussions and challenged Russian and traditional Western critical assertions" (Meng, 2002) so as to respond to Cao Yu's, the previous president of the Chinese Shakespeare Society, call for Shakespearean studies with Chinese characteristics. In his Learning from Shakespeare printed in the People's Daily in 1983, Cao Yu remarked that "our studies of Shakespeare are conditioned differently from our Western counterparts. We have a long cultural tradition.... We approach Shakespeare and admire the 'world giant' with Chinese eyes of a new historical phase.” (Meng, 2002) Subsequently, trying to establish a Chinese style of Shakespearean criticism, scholars and critics no longer followed the traditions of literary criticism of other countries, say, Russian Shakespearean criticism; what is more, instead of criticizing the playwright and his works from the political viewpoint of class struggle - Mao Zedong's guideline for art and literary criticism, they attempted to adopt an artistic approach to appreciate and interpret the humanistic ideas and aesthetic values in his plays and poems. Relatively freed from any political persecution, the Chinese academics increased their interest in the Shakespeare scholarship. Their enthusiasm and devotion were reflected in a series of significant events of Shakespearean studies in modern China.

The Shakespeare Studies, remarked He Qixin, was the first and, so far, the only Chinese journal devoted to a man of letters outside China and the first issue was published in March 1983. In this journal Chinese scholars evaluated Shakespearean dramas from the aspect of humanism while maintaining a Chinese sensibility, that is, Shakespeare's works were interpreted by the Chinese from the perspective of human nature and human rights embedded in the plays, closely combined with the social and political issues in contemporary China. Instead of analyzing the theme of Shakespearean dramas, the Chinese tended to appreciate characters with passion, awakening self-consciousness, desire for freedom and competitive individualism, which inspired emancipation from spiritual fetters and demanded human rights and dignity. Some radical Chinese critics related particular social issues in Shakespeare's dramas to those of contemporary China, for example, the power struggles in the playwright's plays were used to mock the political situation in China.

In the following year 1984, the Chinese Shakespeare Society was founded in the Shanghai Theatre Academy and Cao $\mathrm{Yu}$, a distinguished playwright, was elected president. The first decision made at the inaugural conference of the Society was to establish the journal Shakespeare Studies and to sponsor a Chinese Shakespeare Festival. Accordingly, in April of 1986, the first Shakespeare Festival was held simultaneously in Shanghai and Beijing. This was a significant event in the history of Chinese reception of Shakespeare, showing that Chinese Shakespearean studies reached an unprecedented phase; what is more important, Shakespeare, previously rejected as a cultural agent of Western imperialism by the Chinese, began to be integrated into Chinese society and culture. At the Festival two dozen different companies staged twenty-five plays by Shakespeare within fourteen days. Only two of them were in English and the plays were performed either in spoken drama or in Chinese local style referred to as "Shakespeare in Chinese costumes" (Sun, 2002), ranging from Beijing opera, kunju opera, Shaoxing opera, yиeju to huangmei opera. The success of the Festival attracted and encouraged Chinese enthusiasm for Shakespearean studies. In looking back on the Chinese Shakespeare Festival of 1986, Philip Brockbank called it a Shakespeare renaissance in China: while it was winter for Shakespeare in England it appeared to be spring in China. (Brockbank, 1988) After the first Festival, Bloody Hands, the kunju Macbeth, was invited to attend the Edinburgh International Theatre Festival in 1987 and welcomed by the Western audience. 
Chinese Shakespearean scholars have positively taken every opportunity to associate themselves with international Shakespearean studies and fortunately they have gained international recognition from the world of Shakespeare. In 1980 Lin Tongji (1906-1980) of Fudan University attended the Nineteenth International Shakespeare Conference as the first Chinese scholar with his paper "Sullied is the Word: A Note in Hamlet Criticism". Another example is that at the Twentieth International Shakespeare Conference (1982), Lu Gusun presented his own interpretation from the Chinese perspective in his paper "Hamlet Across Space and Time", which was published in the Shakespeare Survey.

The flourishing reception of Shakespeare in China advanced steadily throughout the 1990s. In 1994, the Chinese Shakespeare Society held the 1994 Shanghai International Shakespeare Festival, attracting three drama companies from Germany, England and Scotland. In addition, the link between Chinese and international Shakespearean studies has been strengthened by China's sending, for the first time, a delegation of twelve professors and scholars to the Sixth Congress of the International Shakespeare Association held in Los Angeles in 1996, and translator Fang Ping's, as the first Chinese, being appointed as a member of the Executive Committee of this international organization. At the end of the twentieth century, the 1998 International Shakespeare Conference was co-organized by the Shanghai Theatre Academy and the Chinese Shakespeare Society in association with the Hong Kong Shakespeare Society and Australian Shakespeare Society. A promising new century of Chinese reception of Shakespeare began.

\section{A Promising Future of ChINESE ShaKesPeAre (The 21st Century)}

Although since the two celebrations in the late twentieth century the Chinese Shakespeare Festival was not carried out on schedule - originally planned once every four years, Shakespearean studies in China made great contributions to translating, performing, teaching and criticism of Shakespeare, which could be seen in the reports of two important conferences: Forum of Chinese Shakespeare in Hangzhou in 2002 as well as Shakespeare and China: Retrospect and Prospect at Fudan University in 2004.

In 2000, a new translation of The Complete Works of Shakespeare in poetic form - the first time in the history of Shakespearean translation - was edited under Fang Ping's guidance. Besides, the Chinese received three versions of Shakespeare's Sonnets between 2003 and 2004, including Wang Yu's Shakespeare's Sonnets, Jin Fayan's Collection of Shakespeare's Sonnets and Ai Mei's Sonnets. In the meantime, many works on Shakespeare came into print, such as Liu Bingshan's A Shakespeare Dictionary for Chinese Students in 2001, Zhang Chong's Topics on Shakespeare in the year 2004 and others.

Even without the professional Shakespeare Festival, performances of Shakespeare have not stopped at universities for instance, the Foreign Languages Institute of Shanghai held several Shakespeare Culture Festivals. The amateur performances of Shakespeare have become popular among universities; for example, the first Competition of Shakespearean Performances at Chinese Universities was given in January of 2005, with more than twenty universities participating in the English contest, including Beijing University, Fudan University, Chinese University of Hong Kong, and Macao University.

What's most striking in this phase was the great development of Chinese Shakespeare criticism. Along with frequent cultural exchange between China and the West, literary and art theories in the West brought to the Chinese new research approaches, broadening Chinese Shakespeare studies and particularly Shakespearean criticism. Among these various methods of researching Shakespeare and his plays, including image study, psychoanalysis, archetypal study, feminism study, religion study, anthropological study, post-colonialism, and deconstruction, cultural studies was the most popular in the Chinese criticism of Shakespeare. The playwright has been compared with Chinese and foreign writers in terms of writing style, theme, plot, characterization and structure. On the other hand, from the dramatic perspective, similarities and differences between Shakespeare's plays and Chinese dramas show the comprehensibility and compatibility of the two cultures, encouraging more adaptations and receptions of Shakespeare on the Chinese stage in the future.

\section{REFERENCES}

[1] Huang, Alexander Cheng-Yuan. (2004). Shakespeare on the Chinese Stage 1839-2004: A History of Transcultural Performance. California: Stanford University.

[2] Chang, Chen-hsien. (1953). Shakespeare in China. Shakespeare Survey, 6, 112-16.

[3] Kennedy, Dennis. (1993). Afterword: Shakespearean Orientalism. In Dennis Kennedy (Eds.), Foreign Shakespeare: Contemporary Performance. Cambridge: Cambridge University Press, 290-303.

[4] Berry, Edward. (1998). Shakespeare East and West. Shakespeare Quarterly, 49, 227-30.

[5] Sun, Fuliang. (2002). Shakespeare in China in the Twenty-First Century. In Kwok-kan Tam, Andrew Parkin, and Terry Siu-hian Yip (Eds.), Shakespeare Global/Local: The Hong Kong Imaginary in Transcultural Production. Frankfurt am Main: Peter Lang, 125-30.

[6] Brockbank, J. Philip. (1988). Shakespeare Renaissance in China. Shakespeare Quarterly, 39, 195-204.

[7] He, Qixin. (1986). China's Shakespeare. Shakespeare Quarterly, 37, 149-59.

[8] Li, Ruru. (1991). Shakespeare Translation in China. Leeds East Asia Papers, 4, 1-25.

[9] Li, Ruru. (2003). Shashibiya: Staging Shakespeare in China. Hong Kong: Hong Kong University Press.

[10] Meng, Xianqiang. (1994). Zhangguo Shaxue Jianshi. Changchun: Northeast Normal University Press. 
[11] Meng, Xianqiang. (2002). The Reception of Shakespeare in China: a Historical Overview. In Kwok-kan Tam, Andrew Parkin, and Terry Siu-hian Yip (Eds.), Shakespeare Global/Local: The Hong Kong Imaginary in Transcultural Production. Frankfurt am Main: Peter Lang.

[12] Zhang, Xiaoyang. (1996). Shakespeare in China: A Comparative Study of Two Traditions and Cultures. London: Associated University Presses.

[13] Mao, Zedong. (1942). Zai Yan'an Wenyi Zuotanhui shang de Jianghua. http: // news. xinhuanet.com/mil/2007-11/24/content_7138256_2.htm(accessed 23/4/2008).

Yanna Sun was born in Henan, China in 1971. She received her PhD. degree in British/American Literature and Culture from Dresden University of Technology, Germany in 2008.

She is currently an associate professor in the Department of Foreign Languages, Zhengzhou University of Light Industry, China. Her research interests include Shakespearean Studies and British/American literature. 